\title{
STRENGTHENING NATIONAL IDENTITY THROUGH TOUR EDUCATION PURBAKALA CIPARI KUNINGAN ARCHAELOGICAL SITE
}

\author{
Ayu Yuliana Priantia* \\ priantiaayu@yahoo.com
}

\author{
Yakub Malik \\ Muhamad Iqbal
}

\begin{abstract}
This globalization era demands the society to be competitive. The society should be able to compete with other countries in the world. The development of science and technology become the keys in facing the gate of the big world. The access of practicality and freedom become the offerings which are inseparable from the society's life. This study is aimed to strengthen national identity through tour education Purbakala Cipari archaeological site in Kuningan regency. Through tour education which contains historical and cultural values, it will lead the citizen to understand their identity as Indonesian which holds unity in the high self esteem. The study used qualitative as the approach and descriptive as the methodology. The data was obtained through observation, interview, documentation study and literature review. The research procedures were deciding the types of data, sources of the data, data collection procedure and data analysis technique. The result of the study showed Pubakala Cipari archaeological site has cultures depicted by prehistory objects and the values on them which appropriate with citizen's identity, especially Indonesian. The general conclusion which can be taken from the study is Purbakala Cipari has been contributed in facilitating an education field for the society and as an inheritance of prehistory it has a big role in strengthening national identity.
\end{abstract}

Keywords: National identity, Tour Education, Purbakala Cipari archaeological site

\section{INTRODUCTION}

Indonesia consists of multicultural society which has identity. Identity is a quality of individual, that differs an individual to others. Identity is marked by uniqueness or individual's personality. National identity is characteristic that differ one country to others. Identity can be seen from culture, education and society. Those three aspects are the unity that can't be separated.

Culture is one of elements that for Indonesia as the country who have different identity from others. Indonesia as multicultural country has various culture in each area. Education is one of efforts in community learning as the place to socialize and embed the culture from generation to generation. According to Soelaiman (2009, pg 53) explains that there is correlation between culture, identity and education. It means that culture generates identity, whereas identity is developed through education. The cultural roots are basically from society itself. Culture is occurred because of the values which are believed and developed by society for the guidance of their lives in order to fit with their goals. The values are for benchmark of society to distinguish what they think is right or wrong. Based on Henslin (2006, pg 48) states that learning individual value, is the idea about life desired. If we reveal individual value, we learn more about it because value is an individual standard determining the right or wrong, good or bad. Value underlines our preference, guide our choice and indicate what we assume worth it in this life. According to Horton and Hunt (in Narwoko and Suyanto, 2007, pg 55) reveal that; "value is idea whether the experience is worth it or not. Value essentially directs to individual's behavior and consideration, but he/she does not judge whether a certain behavior is wrong or right'.

The values in society are adjusted with the needs and society. To be accepted in a society, individual has to be able to adjust himself with the value and society's culture in that area. It does not rule out the possibility with the globalization era with the advanced science, education and technology, one society can exchange the culture from others. Similar, Setiadi and Kolip, (2011, pg 688) explains "he impacts of globalization is intercultural area as if melted becomes global culture". Globalization is part of current culture which is familiar in society life. The existence makes the world as if there is no border. The condition is marked with independence and convenience in obtaining information and communication. the advanced role also supports globalization. Globalization can change and affect to society life in many aspects, such as science, politic, economy, social, culture, defense and security. Development in this era forces society to break through space and time limit to global life. It causes the appearance of higher challenge and competition in society. The heavier challenge encourage society to compete and increase their quality.

This era gives renewal that brings hope and danger. It increases hope in furthering public welfare because human basically is social beings who needs others to fulfil the needs. It is far different from the hope; the other side of this condition can cause risk. Single culture or united culture and the norms can gradually be shifted because dissatisfaction toward what they have. It is similar with argument of Giddens (in Setiadi and 
Kolip, 2011,pg 691) "every country aware that they contribute in world process that changes without any control, it is marked by the taste of interest in the same things, change and uncertainty and also possibility that happens".

To keep the value and culture, it needs socialized efforts for the next generation. Based on Scott (2011, pg. 259) "socialization is the concept which introduces that social, history of individual

is formed in sustainable culture transmission process. The same as Scoot, Nasution (2011, pg 126) explains that "Socialization is process to guide individual to social world, socialization is conducted by teaching individual about culture they have and follow, so that he/she becomes the good member in sharing in certain group."

The risk that appears from globalization can cause moral dedication and good change socially or culture which are in society's environment. The impacts are the loss of nation identity. Nation identity is a concept related to character that distinguish Indonesia and other countries. Nation identity with form of culture values are the result of community association whose environment have complex homogeneity as in Indonesia. Good citizen as Indonesian has duty in defending nation identity as the identity of the country. Nation identity of Indonesia reflects in Pancasilla as way of life in nation and state. One of values in Pancasila is culture. Culture is one of elements that form nation identity as identity because it has model and set of knowledge that are taken from the environment, as things and behavior. In line with Selo Soemardjan and Soelaeman Soemardi (in Soekanto, 2010, pg 151) argues that culture as "all result of works, tastes, inventiveness of society. Works of society generate material culture which are needed human to dominate the environment so that the power can be perpetual for the needs of society".

Talking about the form of culture that is concreate can be depicted with the buildings or things. One of them is cultural heritage. Cultural heritage is the most important heritage of nation that needs to be preserved as identity of the country, which helps in developing knowledge and culture. In line with Salim (2008, pg 12) function of cultural preservation "as the mark of past time, cultural preservation maintained and used to continue ego of human creativity. When it is used in the right way, cultural preservation makes ongoing human identity". Cultural heritage has high enough value in many aspects of life, reviewed from historical background until the study of cultural preservation usage from society and surroundings. Preservation and care of cultural preservation need to be developed by government and society for the sustainability of the next generation.

There are buildings that contain heritage objects from civilization in the past that are made small museum and park with the characteristic of Metalithium buildings, such as coffin grieve, stone terrace and menhirs which are located in Cipari village. It has become tourist object. This finding happens twice in settlement period in $500 \mathrm{BC}$ until $1000 \mathrm{BC}$, those are Neolithic and Megalitic. The findings clearly reflect in detail about organization at that time. That period depicted society's development that knew belief in stone building as media to communicate between human beings and ancestral spirit who passed away. From that believe, people at that time were sure that the good relation with spirit would bring welfare in many aspects in life such as agriculture, farms and others.

There uniqueness become interesting elements in Cigugur Sub-district, especially archaeological sites of Cipari as interesting main topic to be learnt deeper so that government and society can take the benefit of the existing, and society know more about tourism object with benefit education value that is good to continue nation identity as socialization media toward net generation. Based on the explanation above, the question is how depiction in archaeological site of Cipari Kunungan, and how archaeological site of Cipari takes role in contributing as brace of nation identity?

\section{RESEARCH METHOD}

This research was conducted in Cipari Village, Cigugur Sub-district, Kuningan District, in tourist attraction of Archaeological Sites of Cipari. The general purpose of this research was to get information from archeological site of Cipari through educational history tour as tool to strengthen identity. This research was conducted with descriptive method in qualitative approach with collecting data technique that were obtained from observation, interview, literature study and documentation. based on Aevilla et al (in Tuwu, 1993, pg 73) "descriptive research generally consists of kind of things, (1) case study, (2) survey, (3) developmental study, (4) follow up study, (5) trend analysis, (7) correlational study)."

Data processing was conducted based on the result that was obtained from observation in field, interview, literature study and documentation in field. The data was processed according to flow stages which was done with qualitative approach. The stages of processing data were done with triangulation, observation overtime, data reduction, data validation, member check, using reference, drawing the conclusion until presenting the data.

\section{RESULT OF THE RESEARCH AND DISCUSSION}

\section{The history of archaeological site of Cipari}

the beginning of Archaeological site of Cipari was farmland and the garden belonged to Cipari people. Most of Cipari people worked as farmer and cow breeders. It begun with the finding of archaeological thing in prehistoric time when Mr. Wijaya did his farm activity, farmer in Cipari in 1971. The found thing was considered 3000 yeasr old BC. Based on typology and stratigraphy of Cipari Archaeological site, it was estimated getting experience two periods, the end of Neolitic and the beginning of people knowing bronze (perundagian) about 5001000 BC. At that period, society had known several systems such as belief, organization, social, culture and others.

The transition between Neolithic and bronze were wellknown with megalithic period. Megalithic was a society tradition in big stone period. Big stone had various forms that 
were different and adjusted by the function. In megalithic tradition, society believed there were relation between death and life. People believed that death people were still alive, they just moved to eternal nature but people and death people could communicate. The media which was used was building the monument of stone as the coming mark of death people's spirit, medium of respect, symbol of goodness/charity/service of individual and it was ended with ceremonial and party.

The area of Cipari Archaeological site is $7.000 \mathrm{~m}^{2}$, but the area was extracted of $2500 \mathrm{~m}^{2}$ by divided 11 square with the depth of 1-2 meters. The width of the building is $700 \mathrm{~m}^{2}$, with the limit of north site, the south of settlement, the east of garden and west of settlement. Location coordinate point is $06^{\circ} 57^{\prime}$ $741 "$ LS and $108^{\circ} 28^{\prime}$ 156" BT with $668 \mathrm{~m}$. Cipari Archaeological site is managed by tourism and culture departments of Kuningan District, BPCB Serang, and BPKSNT Bandung. The location $\mathrm{f}$ Cipari Archaeological site is right in mountain slope of Ciremai. There are many arguments revealing that if location of Cipari, especially the location of Cipari Archaeological site if it is done the excavation more, there will be more archaeological things. It is strengthened with ancient human culture in megalithic tradition that had known several life systems such as how to grow crops, breeding and living in one places. That culture of society is reflected in the location of Cipari that directs on suitable characteristics. It is not far from the location of Cipari, there is a lake and water sources. Cipari Village is also between 2 two big rivers, Citaba and Cigugur river. The name of Cipari was taken from that condition. Cipari consist of $\mathrm{Ci}$ and Pari. $\mathrm{Ci}$ means water and Pari means inundation, if it is united become puddle. Whereas there is no special name of Cipari Archeological site. The given of the name was adjusted with the type of location and finding type regarding the period of ancient human. So, the name is officially Cipari Archaeological site.

Other supports that encouraged the lives of ancient people in Cipari village was the finding of tools and equipment of ancient people in that period such as stone axes, pendil, jambaran, kekeb and others. Tools and equipment's that were found were not in intact condition. The function of tools and equipment of ancient people leaded to to megalithic tradition which reflected the human in that period who has had developed. If it is studied deeper, people in megalithic has had been able to do food producing. The ability was strengthened by the tools such as kekep, vagatable rings and on the equipment which were found in Cipari Archeological sites.

\section{Education of Historical Tour Cipari Archeological Site, Kuningan}

Establishment of Cipari Archaeological Site has helped people in many aspects especially in education and formal and informal learning. The given facilities are enough to support those activities. The facilities are such as museum of ancient things, ancient park which is located in front of museum, custom house of sunda, Booklet as guide tool for tourists regarding information of ancient things and the history of Cipari Archeological site, tourist guides who take role in guiding the place tourist haven't known yet and Kuningan District museum that has been lately established which informs regarding culture and sites in Kuningan District. In line with Roppolo (1996, pg 191) states "countries become interdependent, their success, economic growth and welfare will really depend on ability of two industries, education industries and tourism industries to create the ways which are needed to support international exchange and learning".

The facilities give education to people, especially the visitor. Besides giving the real education, Cipari Archaeological Site can give education value. If it is reviewed, the values reflected ideology of Pancasila which is as guideline to live nation and state in Indonesia. The value is saved in concreate culture as tools and equipment of ancient people. Abstract value also reflected in their activities such as ceremony and ritual. In line with Koenjraningrat (1974,pg 15) that stated 'the culture form consists of three complex things such as ideas, notion, values, norms, rules, others, culture as complex activity from behavior pattern of human in society, culture as things from human work,"

Cipari Archeological Sites is the evidence that can be learnt and understood. There are many life values taken from past time that can be implemented at this time and in the future; value of belief, knowledge, organization until economic.

The beliefs are someone belief toward things they are sure about. Indonesia had had ensured the independence for each person to believe in religion according to what they are sure, based on the constitution. Religion is the most important aspect for people as basic life of people to control their selves. The function of religion is not only for the past, current and in the future, but also for living in earth and hereafter. The religion has existed since ancient era. People in pre- historic time called the religion with term of belief. The meaning that was taken from the location is the higher symbol of media reflected human, the closer relationship with god. God has highest position. Media of big stone is called menhir. There are not many numbers of menhir or it usually is only big one. It gave symbol that human had to focus in one thing, eternal life. Upright position meant with the good life as applicable provision.

Cipari Archaeological Site is estimated of one of history evidences ancient people of Homo Sapiens that ever stayed in Cipari village at transition time, the end of Neolithic and the beginning of bronze. At that time, it resulted many cultures. It is well-known as megalithic tradition or the era of big stone. The human works result in Megalithic era were menhir, stone altar, dolmen and coffin grave. four things were made of big stone and they are rough without smoothing process. The function of four of them were not really different. Menhir, altar stone and dolmen were used as communication tools from human to God, spirit and death people. People in prehistoric believed that each soul would always live, what make them different was real and mortal. The good relationship was not only between the people but also the with God, and death people. They often did ceremony, ritual and worship. Big stones 
were symbol and media. Storage location of the ancient things was on the hill of the higher surface.

It was not far from the belief of God; pre-historic people were sure the good relation with the nature had to be maintained. Nature is the important component of life. People at that time did ceremony to thankful to god. It was not far from Cipari Village, thankful tradition to God and nature are still done by people in this era, the name of the ceremony is seren taun.

Knowledge is determining aspect in a civilization. People usually think that a person is determined by the level of his/her formal education. The culture has spread and become parameter of smart and intelligent of a person and social status. Indirectly, knowledge can be obtained by all people without limit, from the smallest aspect until complex ones. Besides, people think that this current civilization has advanced with the technologies among the people. Unconsciously, the impact is getting bigger and it can threat human life.

Before the modern, people of pre-historic had high ability and knowledge. The knowledge was seen that they knew about astronomic and could read it in determining for the interest of daily life, such as farming and others. Coffin grave that were in Cipari Archaeological site was not only for bury the death bodies. Place and position of coffin grave had the philosophy meaning. Coffin grave of Cipari Archaeology Site was head west and east. The did not deify the sun but they were guided of the round of the sun as the single energy that gave lives ti plans, animal and human. Form the coffin grave, it could be seen suitable season in Indonesia. The big coffin grave gave symbol of the good month to do the farm. Whereas the small coffin grave marked the month of rain and dry season. Astronomic knowledge was used in pre-historic period, the source was strengthened with the location of Cipari that has fertile soil and water sources. People in megalithic tradition has begun to live and do the farming. Until now, farming is still done by Cipari people. It was different from pre-historic, Cipari people now count astronomic with name of pramnata mangsa. Pranata mangsa is marked by the existing of coffin grave in Cipari Archaeological Sites. If coffin grave shifts and a little bit open, it means that dry season is coming. Planting in forest can't be done because the plants will not grow. Yet, if coffin grave shifts back, the farmers begin to process the fielt. Some people in Archeological site look the animal with many marks. When there are many larons, people do not dare to plant beans. They believe that even though the bean will grow, the result is not good. If people see the shoot of gadung tree, planting all kind of plants will be good even though the field is dry because of dry season.

Organization is the set of corporations of group of people with the certain purpose. Organization system of pre-historic people reflected with the finding of circle stone in Cipari location. The finding is the set of stones that form circle with a stone as the center. From the things are reflected the focus of leadership. with the mark of a stone as the center of circle, the shape of the circle stone reflects that the organization of pre- historic was existed. It is estimated that the gathering was for discussing. Other support things are dolmen and big table that function as storage of offerings for worship. Dolmen is for the throne of king/leader/ the oldest customary figure. The time of pre-historic has known the leadership to maintain social life. Currently, organization is still used by people to place many problems. Organizational system can be seen in government department that maintain the case of society. Social life at prehistoric and current social life are far different. Basically, the life of pre-historic is grouped living and they depend one for another for all activities, such as hunting, farming and more. Social life of pre-historic can be observed from the way of living. The stages of pre-historic human living began with hunting. In this step, someone was impossible to do it alone with the simple tool. In addition, people $\mathrm{f}$ pre-historic had known of dividing work assignment. The men were hunting animal, whereas women did the gathering. It can be said that they had known aspect of life. Positive value that can be taken from their lives are mutual cooperation and community of cooperation. People at pre-historic tried to find place to do the activity of settlement. Cipari people made the tradition which is popular with Babarit. Babarit is gathering in Cipari Archeological site slaughtered livestock then it is cooked and consumed over there.From people economic, this tourist attraction can open business opportunity by opening business near the tourist attraction such as small store, typical works from Cipari, etc. At that time, people who lived near the siteswell-known as craftmen/ceceting. But they seldom make the kind of craftmen.

Economic system in pre-historic had happened. Not all people know that people pre-historic has determining economic system. People maybe thing that ancient people could not do the transaction. The fact, they have determined barter (change system). They usually changed the result of farming, breeding or other result of wrong. There are many value that can be taken from pre-historic period. It is important for people to know about their country's history. The knowledge of history will help people to love more about the country. Indonesians should be proud that they were born in the fertile soil, having many culture and languages.

\section{The Role and The Contribution of Cipari Archaeological Site as The Tool to Strengthten National Identity}

Cipari Archaeological site is one of heritage from prehistoric in Kuningan District. There are many cultures that should be known over there. The culture can be seen from the findings such as tools and equipment of ancient people, that were made of simple ingredients which were available in nature near them. The purpose was to fulfill the needs of their life. Cipari Archaeological site is the tourism object which is managed by department of culture and tourism. The role of Cipari archaeological site as the national identity is obtained through socialization. The way to socialize emphasizes the role of Cipari archaeological site as tourism object of education for society.The contribution of Cipari archaeological Site is not easy in implementing the power of national identity. The 
obstacles usually appear. So far, the obstacles faced affect Cipari archaeological site. The obstacles usually come from internal and external Cipari Archaeological site. The location of Cipari is predicted to have big potential in saving ancient things more that people know. The potential is seen from the found things and knowledge and sciences which encourage that Cipari is one of location ancient people ever lived. If the area is excavated deeper, it possibly will find more ancient things and the side can be enlarged more. The plan is a good idea and it needs to be supported. However, in implementing the plan, there are always obstacles such as the lack of scientist and society's intention and the lack of financial. The alternative to attract the site is melting the pre-historic culture with Sundanese culture. The concept is conducted by building Sundanese traditional house. But the obstacle of the lack of financial does exist.

Appropriateness of Cipari Archaeological site as education tool for society is seen from culture value and tradition. The opinion is proved with the existing of abstract and concrete culture of Cipari Archaeological site. At glance, Cipari Archaeological site is more dominated by the culture of things such as Menhir, dolmen, dakon, altar, coffin grave and many tools/equipment. But they are studied deeper, Cipari Archaeological site had abstract culture as idea/concept in implementing the life of ancient people such as belief, social, knowledge, economic etc. The cultures are tradition of ancient society that was predicted in the end of Neolithic and the beginning of bronze. The culture was in between those both periods that was well-known as Megalithic. Megalithic tradition is society tradition of ancient people with big stones. The stones were adjusted to the needs of people at the period.

The culture in the heritage should be embedded to young generation through good education, culture. However, the reality of current education is establishing the society oriented to globalization and it is not suitable with the national identity. For example, the decreasing of unity and justice. Now, culture is changed by power culture and individualism. Society behave that they do not care about nature environment, social and their own culture. It is clear that the identity of Indonesia is depicted and it becomes the guideline to live in nation and state. The explanation is strengthened in UU 1945 which is revealed in Panacasila and the points that explains Indonesia has high culture with holding the values of God, Humanity, Unity, Deliberation and Justice. In line with Ki Hajar Dewantara (in Sa'adah, pg 151) explains that in education principle, there is culture principle, education is from the culture of the nation, but it follows the external culture according to the period. The real of points in pancasila can be seen in the form of culture in Cipari Archeological Site. Five points that were held by Indonesians the form of national identity also reflect to surrounding environment. The value of God can be seen in the belief of ancient people in pre-historic in menhir, the big straight stone. If it is observed, belief had existed and developed in civilization. Human had been able to appreciate and respect the surrounding environment. The belief was that life will go on even though the person died, there would be another life.
The other point is about humanity. Humanity concept in megalithic culture was formed in behavior in corpse burial. Corpse burial in megalithic period reflected that before people knew education, life had been civilized as the tradition which was done by society. People really appreciated death people and treat them well. They buried the corpses in grave crates with the things they needed and liked when they were still alive. The value thought that every human has to be treated well and fair.

Whereas unity value can be seen in human in pre-historic in group. Group culture which about living together was inherited to the previous generation, especially for Cipari society that had Babarit tradition, the tradition of slaughtering animals which then were cooked and served in Cipari Archaeological site. The tradition is no longer to be done. It can be estimated that the tradition was lost because of urbanization flow. People have desire to develop the life, in education, economic and other aspects. The condition gradually will scrape existing culture and form the new culture of society.

Other values are deliberation and agreement perceive in the thing of circle stone, circle stonein Cipari Archeaological site. The value is about leadership and organization based on deliberation and agreement in society. Society of pre-historic though more complex in fullfiling the needs of their lives.

And the value of justice perceive in the form of farming tradition which was done by antient people that characterize in the form of culture thing such as stone axes and others. People in pre-historic were able to cooperate in processing the field mutual prosperity. Based on the finding of ancient things in Cipari Archaeological sit, it can be predicted that people at that time were the human in the stage of farming. Ancient people in this stage were called as megalithic people. It is because the findings have good quality like other stone.

These kind of values are shifted. Philoshopy as life guidance of society has not implemented. The freedom and the way to live are wraped and protected by the law. In fact, the policy was made like forcing the society and their lives. It affects the decreasig of the love for the country. The lack of trust for the country is one of the big problem of Indonesia. The kind of problem will fade the identity of Indonesia. It is not easy to solve. It needs attention and cooperation from society and the gvernment. Recent study in Cipari Archaeological Site influences society's education. Self0awereness, certain limits, continuity of place and time, communication, interaction, integration, short-term and long-term visions, media assessment and responsibility are affected by variable education of Cipari Archaeological site. Self-awereness about the uniqueness of past time and the importance of the anchient things that are placed in the museum are the depiction of selfawereness quality collectively. Even though from the interview, there is possibility that people claim in owning the ancient things, bu because of the existing of this site, people aware to put the ancient things in Cipari archaeological site. The purposes of people visiting the museum are various. They usully visit to do the task, vacation, curiosity and others. 
Geograpical location of Cipari Archealogical Site is near to the middle of city or the main road, so that it easeas visitor to come. However, the lack of street signs need to be added by the government. Visitors will understand easily abut the information about all things in Cipari Archaeological site because the tour guides has good ability in Indonesia. The knowledge about the findings help visitor to understand about the things that their ancestors made. However, the Cipari archaeologial sites is not just showing the ancient things but also giving the information about culture at that period (handelem or hanjuang). People needs to know the history to strengthen the identity of Indonesia that has gone such as babarit. Visitors also have many expectations after visiting Cipari Archaeological site such as preservation and he care of the ancient things and the facilities. People know that one of ancient thing that has been used until now is cobek. Cobek is tool to smooth the spice. From the data, it results that people usually only one-time visiting Cipari Archaeological site. It is indicating that the site does not make people really interest. Government should find way to solve this problem because this place is typical tourist attraction. The $Y$ should add facilities, make the location lager, add other content such as culinary, tourism of creative economy of water recreation because Cipari is among the rivers.

Ancient things found in the whole state but sometimes it is not. Intact condition usually things as tool for daily life equipment such as kendi and vegetable basket. The things which are not in intact condition found in pieces. The broken ancient things are predicted that there was earthquake at that time. The ancient things that have never seen by people usually make them curious. It establishes the understanding about diversity. And visitors from other place from Kuningan, they get the information about the cipari from media. The data which is obtained shows the lack of visitors outside Kuningan District. It is implicated from the lack of socialization about the place.

Detail information about the stone for the equipment of Cipari Archaeological site is should be socialized to visitors and society. The right and clear information will add the knowledge and open people's mind. The important of socialization is to keep and save the national identity and keep the culture. In line with Koentjaraningrat (2009, pg 189) "enculturation process is the process of individual to learn and adjust the mainset and the behavior with custom, norm system and the rule of life in the culture." It can be seen that visitors more like the ancient things. The findings is, there is no education about archaeological so that there are people who do not want give the ancient things they found to the authority. Whereas responsibility is one of aspects to esthamblish national identity. So far, management, visitors and several people of Cipari take role to the preservation.

\section{CONCLUSSION}

Based on the explanation above, it can be concluded that the Cipari Archeological Site has quality of educative and heritage. The location is in Cipari village, Cigugur Sub-district, District of Kuningan. This site was build for educative object that can be learnt by people.

Infrastructure of Cipari Archaeological Site fulfill the needs of society, especially in sectors of education and science. The facilities are ancient things museum, cipari park, booklet, guide and others. However, the facilities have to be improved for visitors. The kind of ancient things are such as menhir, coffing grave, dakon, dolmen, stone altal and any other equipment gat that time like kekeb, pendil, kendil, etc.

This site has big role to strengthen national identity because it saves the values and cultures that reflect Indonesians' identity. The values are belief, knowledge, organization, social and economy. The values are good as guide or base in people's life as Pancasila. The education tourism affects the identity of Indonesia such as the first point about God was in Menhir with the tradition of worship, the humanity in coffin grave with the tradition of burrying, unity in the tradition of babarit and agreement in circle stone and justice is in stone axes with the tradition of farming

\section{REFFERENCE}

Henslin, J.M. (2006). Sosiologi dengan Pendekatan Membumi "Essentials of Sociology". Jakarta: Erlangga

Koentjaraningrat. 2009. Pengantar Ilmu Antropologi.

Jakarta: Rineka Cipta

Koentjaraningrat. 1974. Kebudayaan mentalitet dan pembangunan.

Jakarta: PT. Gramedia

Narwoko, J.D \& Suyanto, B. (2007). Sosiologi Teks dan

Pengantar Terapan Edisi Ketiga. Jakarta. Kencana

Nasution, S. 2011. Sosiologi Pendidikan. Jakarta: Bumi

Aksara

Salim, A. 2008. Pengantar Sosiologi Mikro. Yogyakarta:

Pustaka Pelajar

Scott, J. 2011. Sosiologi The key concepts. Jakarta:

Rajawali Pers

Setiadi, E.M \& Kolip, U. 2011. Pengantar Sosiologi.

Jakarta : Kencana

Sevilla, C.G, Ochave, J.A, Punsalan, T.G, Regala, B.P, dan Uriarte, G.G. (1993). Pengantar Metode Penelitian. Jakarta. UI-Press

Soekanto, Soerjono. 2007. Sosiologi Suatu Pengantar. Jakarta: PT RajaGrafindo Persada

Roppolo, C. International education: What does this mean for universities and tourism? In M. Robinson, N. Evans and P. Callaghan (Eds) Tourism and Cultural Change. Hlm. 191-201. Sunderland: Centre for Travel and Tourism and Business Editorial Press..

Sa'adah, Zumrrotus. 2015. Jati Diri Bangsa dan Potensi Sumber Daya Konstruktif sebagai Aset Ekonomi Kreatif Indonesia. 11(2), hlm 151 (Jurnal Economia, volume 11, nomor 2, Oktober 2015)

Soelaiman, D.,A. 2009. Pendidikan dan Kebudayaan sebagai Sarana untuk Memperkuat Jati Diri Bangsa. Jurnal Pencerahan Pendidikan. 6 (2), hlm. 53 